\title{
ANALISIS PEMAHAMAN GURU TERKAIT KONTEN GEOMETRI DALAM IMPLEMENTASI PEMBELAJARAN
}

\author{
Siti Ramdhayani Litiloly ${ }^{1}$, Nurjanah Salampessy ${ }^{2}$ \\ Dosen Program Studi Pendidikan Matematika, STKIP Gotong Royong Masohi, Maluku Tengah ${ }^{1,2}$ \\ e-mail: ani.litiloli@gmail.com
}

\begin{abstract}
ABSTRAK
Menjadi seorang guru merupakan suatu tindakan yang mengharuskan seseorang perlu memiliki pemahaman yang baik akan dirinya, peserta didiknya, dan materi yang akan disampaikan. Potensial pemahaman konten geometri oleh seorang guru dapat mejadikannya memiliki kualitas mutu yang baik dan profesional pada materi tersebut. Namun bagaimana jika guru tidak memiliki pemahaman yang matang dan baik terkait konten geometri. Bagaimana dengan pengajarannya kepada peserta didiknya. Oleh karena itu, tujuan dari penelitian ini adalah untuk mengetahui bagaimana pemahaman guru terkait konten geometri dalam implementasinya. Adapun penelitian ini menggunakan pendekatan kualitatif deskriptif, dan hanya difokuskan untuk memperoleh informasi tentang pemahaman guru terkait konten geometri, yang selanjutnya dilakukan analisis. Subjek ataupun responden adalah tiga guru matematika sekolah menengah di Lisabata Timur, Seram Utara Barat, Kabupaten Maluku Tengah. Penelitian dilakukan melalaui tahapan observasi pembelajaran, pengisian angket pemahaman, tes pemahaman, dan wawancara. Hasil penelitian diperoleh bahwa perencanaan pembelajaran yang tuliskan oleh guru dapat dikatakan baik dan mengikuti kebijakan K-13, namun pada pelaksanaan tidak sesuai dengan rencana tersebut. Sedangkan pada tes pemahaman terkait konten geometri, masih terdapat guru/responden yang keliru dalam menyelesaikan tes. Namun, terdapat satu responden yaitu responden 2 yang mana responden tersebut lebih memahami dengan baik terkait konten geometri dari pada dua responden lainnya. Meskipun terdapat responden yang telah baik dalam perencanaan pembelajaran dan pemahamannya terkait konten geometri, namun masih memerlukan usaha lanjut olehnya untuk menjadikan pembelajarannya lebih baik.
\end{abstract}

\section{Kata kunci :}

Pemahaman guru terkait konten geometri; Pemahaman dan implementasi.

\begin{abstract}
Being a teacher is an action that requires a person to have a good understanding of himself, his students, and the material. The potential for understanding the content of geometry by a teacher can make it good and professional quality in the material. But what if the teacher does not have a mature and good understanding of the geometric content. How about teaching to students. Therefore, the aim of this research is to find out how teachers understand the geometry content in its implementation. This research uses a descriptive qualitative approach, and only focused on obtaining information about the teacher's understanding of the geometric content, which is then analyzed. The subjects/respondents were three at high school mathematics teachers in East Lisabata, West North Seram, Central Maluku Regency. The research was conducted through the stages of learning observation, understanding questionnaires, comprehension tests, and interviews. The results showed that the learning planning by teachers can be said to be good and follow the K-13 policy, but the implementation is not in accordance with the plan. Whereas in the comprehension test related to the geometry content, there were still teachers/respondents who made mistakes in completing the test. However, there is one respondent, namely respondent 2, in which the respondent understands the geometric content better than the other two respondents. Even though there were respondents who were good at learning planning and understanding related to geometry content, they still needed further efforts by them to make their learning better.
\end{abstract}

\section{Keywords :}

Teachers understatnding of content geometry; Understanding and impementation 


\section{$\pi$ (Phi)}

\section{PENDAHULUAN}

Guru dikatakan sebagai salah satu penentu kualitas pembelajaran di sekolah yang mampu menyesuaikan dengan perkembangan zaman (Ekowati, 2017), sehingga menjadi profesional dibidangnya. Mengutip pada Pournara et al. (2015) bahwa selalu ada upaya untuk meningkatkan pengetahuan matematika guru. Yang mana upaya ini dilakukan dengan tujuan untuk meningkatkan mutu pendidikan yang didalamnya termasuk pada peningkatan kualitas profesionalnya seorang guru.

Menjadi seorang guru merupakan suatu tindakan yang mengharuskannya perlu memiliki pemahaman yang baik tentang dirinya, peserta didiknya, maupun materi yang akan disampaikan. Hal ini karena pengetahuan guru sangat penting dalam semua konteks pembelajaran (Pournara et al., 2015).

Suatu pembelajaran didalamnya terdapat kategori kemampuan peserta didik (Said \& Budimanjaya, 2015) dan bagaimana guru mengajarkannya. Potensial pemahaman materi matematika dalam hal ini konten geometri oleh guru, menjadikannya semakin memiliki kualitas mutu yang baik dan profesional pada bidang tersebut. Ini berarti guru tidak hanya mengasah pada pengetahuan peserta didik, namun pada tingkat pemahaman yang lebih baik olehnya terkait konten matematika. Hal ini sejalan dengan penelitian yang menyatakan bahwa guru yang memiliki pemahaman dan pengetahuan yang lemah, akan memberikan dampak yang kurang baik bagi peserta didiknya (Pournara et al., 2015)

Yilmaz et al. (2005) mengemukakan bahwa peserta didik memiliki kesulitan dalam memahami geometri. Jika peserta didik dapat memahami salah satu konsep dengan baik, maka akan mempengaruhi konsep terkait selanjutnya (Nasution, 2018). Oleh karena itu, guru harus memiliki pengetahuan mendalam tentang matematika spesifik yang diajarkan (Ball, 2000), serta matematika yang akan dipelajari dimasa depan karena pengetahuan guru berdampak pada perilakunya, sehingga secara tidak langsung mempengaruhi prestasi belajar peserta didik (Muijs \& Reynolds, 2002; Sunzuma \& Maharaj, 2019).

Guru yang kurang memiliki kemampuan untuk mengajarkan geometri akan menemukan masalah ketika ia tidak memperhatikan kesulitan peserta didiknya (Gal, 2011; Kılıç, 2011; Kuzniak \& Rauscher, 2011). Selain itu, salah satu alasan kurangnya kinerja matematika dalam geometri karena minimnya pengetahuan konten geometri dan penggunaan metode pembelajaran yang belum sesuai (Chiwiye, 2012; Mashingaidze, 2012).

Oleh karena itu, kualitas dan mutu seorang guru dalam tingkat pemahaman akan konten geometri sangat amat dibutuhkan. Membahas geometri, berarti membahas teori Van Hiele. Teori Van Hiele digunakan tidak hanya untuk mengukur kemampuan peserta didik, namun dapat juga untuk menguji pengetahuan guru terkait konten geometri dalam mengidentifikasi tingkat argumentasi atau pemikiran geometris peserta didik (Hiele, 1959). Shulman mengungkapkan bahwa terdapat enam domain pengetahuan guru (Ball et al., 2008).

Yang mana tiga domain berada pada pengetahuan materi pelajaran, sedangkan tiga domain lainnya berada pada pengetahuan konten pedagogis (Sandt \& Nieuwoudt, 2003). Pengetahuan tersebut penting untuk setiap materi termasuk materi geometri, dimana geometri menjadi topik yang terus diterapkan dalam kehidupan sehari-hari namun sering diabaikan dalam kurikulum (Tutak \& Adams, 2015).

Jika guru memahami dengan baik konten geometri yang akan diajarkan maka ia akan lebih siap untuk mengajarkannya. Selain itu, pemahaman guru akan konten geometri menjadikan ia akan menyiapkan berbagai penyajian dalam implementasinya.

Bagaimana jika guru tidak memiliki pemahaman yang matang dan baik terkait 


\section{$\pi$ (Phi)}

konten geometri?. Bukan menutup kemungkinan bahwa guru harus mempelajari dan memahami dengan benar sebelum mengimplementasikan.

Oleh karena itu penelitian ini bertujuan untuk menganalisis pengetahuan dan pemahaman konten geometri pada guru matematika sekolah menengah di Lisabata Timur, Seram Utara Barat Kabupaten Maluku Tengah.

Adapun state of the art pada penelitian ini diambil dari dua penelitian sebelumnya, yaitu pada penelitian yang dilakukan oleh Suriza van der Sandt dan Hercules D Nieuwoudt tahun 2016 tentang "Grade 7 teachers and prospective teachers content knowlegde of geometry" dan penelitian oleh Gladys Sunzuma dan Aneshkumar Maharaj tahun 2019 tentang "In-service teachers geometry content knowledge: Implications for how geometry is taught in teacher training institutions". Adapaun persamaan kedua penelitian diatas dengan penelitian ini adalah mengetahui bagaimana tingkat pemahaman konten geometri oleh guru matematika. Sedangkan yang menjadi perbedaannya adalah penelitian sebelumnya hanya berada pada calon guru matematika dan guru yang mengajar pada kelas 7 saja. Sedangkan penelitian ini dilakukan pada guru matematika pada jenjang sekolah menengah pertama dan menengah atas di Lisabata Timur.

\section{METODE PENELITIAN}

Penelitian ini difokuskan untuk memperoleh informasi tentang pemahaman guru terkait konten geometri, yang selanjutnya dilakukan analisis.

Pendekatan penelitian yang digunakan adalah kualitatif deskriptif. Yang mana penelitian ini memaparkan hasil yang diperoleh secara analisa dan terdeskripsi. Adapun yang termasuk dalam subjek penelitian ini adalah dua guru matematika di jenjang SMP dan satu guru matematika di jenjang SMA. Hal ini karena pada daerah Lisabata Timur hanya terdapat dua SMP dan satu SMA, yang mana guru yang bersedia untuk diteliti adalah tiga dari lima orang.

Adapun tahapan dalam penelitian ini, sebagai berikut:

1. Observasi terkait kegiatan pembelajaran

2. Survei terkait pemahaman konten geometri dalam implementasinya (pengisian angket pemahaman konten geometri dan tes pemahaman)

3. Wawancara

4. Studi dokumen yakni rencana pembelajaran yang disiapkan terkait konten geometri.

Dengan melihat pada tahapan penelitian diatas, maka instrumen yang digunakan dalam penelitian ini meliputi: lembar observasi kegiatan pembelajaran, lembar angket pemahaman konten geometri dan tes pemahaman yang terdiri dari tiga soal, wawancara, dan dokumentasi. Data yang diperoleh kemudian dianalisis.

\section{HASIL DAN PEMBAHASAN}

Pada tahapan analisis, diperoleh bahwa responden memahami dengan baik akan penggunaan kurikulum 2013, namun pada penerapannya tidak dapat dilaksanakan dengan baik. Meskipun kurikulum 2013 merupakan kebijakan dalam pendidikan sekolah namun praktek penerapannya mengikuti kondisi peserta didik pada ketiga sekolah tersebut.

Selain itu, pada dokumen rencana pelaksanaan pembelajaran sangat tertata dengan baik tahapan pembelajaran yang dikolaborasikan dengan berbagai model dan metode pembelajaran yang dapat mendukung terjadinya interaksi dan pemahaman yang baik akan materi yang disampaikan, namun pada pelaksanaannya justru berbeda. 
Tabel 1. Kesiapan dokumen RPP dengan imlementasi pembelajaran

\begin{tabular}{lccc}
\hline \multicolumn{1}{c}{ Sekolah } & Jumlah & RPP K-13 & Implementasi Sesuai \\
& Guru (responden) & RPP K-13 \\
\hline SMPN 5 Seram Utara Barat & 1 & Ya & Tidak \\
SMPN 6 Seram Utara Barat & 1 & Ya & Kadang \\
SMAN 49 Maluku Tengah & 1 & Ya & Tidak \\
\hline
\end{tabular}

Perlu diketahui bahwa, jumlah guru matematika pada SMPN 5 Seram Utara Barat hanya dua guru, dan yang bersedia untuk diteliti adalah satu guru. Sedangkan pada SMPN 6 Seram Utara Barat hanya terdapat satu guru matematika. Selanjutnya, pada SMAN 49 Maluku Tengah terdapat dua orang guru matematika, namun hanya satu guru yang bersedia untuk diteliti.

Pada tabel 1 (diatas), terlihat bahwa guru matematika membuat perencanaan pembelajaran sesuai dengan kebijakan K-13. Namun pada pelaksanaannya tidak dapat diimplementasikan. Sehingga, ketika dilakukan wawancara diperoleh bahwa:

Tabel 2. Wawancara kesiapan dokumen pembelajaran (beberapa bentuk pertanyaan)

\begin{tabular}{|c|c|}
\hline Guru (responden) & Pertanyaan wawancara \\
\hline Responden 1 & $\begin{array}{l}\text { 1. Apakah Ibu membuat sendiri RPP } \\
\text { sesuai dengan kebijakan K-13 ? } \\
\text { 2. Apakah seluruh yang tertulis pada } \\
\text { rencana pembelajaran terlaksana pada } \\
\text { kelas yang ibu ajarkan? } \\
\text { 3. Jika begitu, implementasi yang ada } \\
\text { pada pembelajaran terkait konten } \\
\text { geometri termasuk dalam perencanaan } \\
\text { dengan kurikulum yang mana? }\end{array}$ \\
\hline & $\begin{array}{l}\text { 4. Menurut Ibu apakah fakta, konsep, } \\
\text { prinsip, dan prosedur dalam konten } \\
\text { geometri penting untuk diajarkan? } \\
\text { Dan bagaimana Ibu mengenalkan } \\
\text { kepada peserta didik (dalam RPP)? }\end{array}$ \\
\hline Responden 2 & $\begin{array}{l}\text { 1. Apakah Bapak membuat sendiri RPP } \\
\text { sesuai dengan kebijakan K-13 ? } \\
\text { 2. Apakah RPP K-13 yang Bapak buat } \\
\text { benar-benar diimplementasikan dalam } \\
\text { kelas yang Bapak ajar? }\end{array}$ \\
\hline
\end{tabular}

3. Pernahkah Bapak menyajikan materi matematika terkait konten geometri kepada siswa dengan kurikulum saat ini ?

4. Menurut Bapak apakah fakta, konsep, prinsip, dan prosedur dalam konten geometri penting untuk diajarkan?
Jawaban responden

1. Iya, RPP dibuat sendiri

2. Tidak, karena jika menggunakan RPP K13 itu justru akan sulit bagi peserta didik

3. Misalnya saja, untuk materi bangun datar. Saya tidak terfokus harus menggunakan kurikulum yang mana, tapi bagaimana pembelajaran itu sampai pada peserta didik.

4. Iya, itu penting.

Kalau itu langsung saya berikan dalam bentuk contoh soal saja. Supaya siswa lebih paham

1. Iya, RPP dibuat sendiri

2. Kadang-kadang. Karena kadang saya juga menggunakan kurikulum KTSP dalam penyajian materi matematika. Jika memaksakan dengan full K-13 pada peserta didik saya, maka akan sulit mengajarkan materi.

3. Geometri, berarti bangun datar yaa.. Kalau itu, saya pernah mengajarkan dengan K-13. Karena kalau bangun datar, biasanya saya meminta siswa untuk melihat disekelilingnya, kan kalau bangun datar lebih mudah jika menggunakan K-13. Karena peserta didik dapat mengenal dan mencari sendiri atau dalam kelompok.

4. Iya penting, peserta didik harus mengenal itu dulu supaya lebih memamahi isi materi selanjutnya. 
Dan bagaimana Bapak mengenalkan kepada peserta didik (dalam RPP) ?
Responden 3
1. Apakah Bapak membuat sendiri RPP sesuai dengan kebijakan K-13 ?

2. Jika begitu, implementasi yang ada pada pembelajaran terkait konten geometri termasuk dalam perencanaan dengan kurikulum yang mana?

3. Menurut Bapak apakah fakta, konsep, prinsip, dan prosedur dalam konten geometri penting untuk diajarkan? Dan bagaimana Bapak mengenalkan kepada peserta didik (dalam RPP)?
Diawal pembelajaran saya membawa siswa untuk melihat dan menemukan bentuk dari misalnya persegi. Dari persegi kan bisa dilanjutkan untuk membangun konsep dari segitiga dan luas segitiga juga. Bisa juga pakai media begitu

1. Tidak, tapi saya sedang belajar membuatnya sendiri

2. Saya lebih suka mengajarkan materi dengan tidak melihat pada kurikulumnya. Tapi mengikuti materi yang akan diajarkan kepada peserta didik, dan melihat kemampuannya.

3. Hal itu memang penting bagi peserta didik. Kalo mengajarkannya bisa dengan lingkungan sekitar untuk lebih paham konsep dari geometri begitu
Berdasarkan tabel diatas, diketahui bahwa lingkup pemahaman dan daya serap siswa menjadi hal utama yang diperhatikan oleh guru matematika. Sehingga bentuk saintifik yang diusung oleh K-13 dan menganut prinsip bahwa peserta didik belajar secara mandiri dan menyesuaikan dengan pengalamannya menjadi sulit untuk diterapkan, mengingat peserta didik masih sangat membutuhkan guru sebagai sumber utama bukan sebagai fasilitator.

Selain itu, ketiga guru juga mengakui bahwa ketika menyajikan materi matematika kepada peserta didik, sangat dibutuhkan kreativitas guru. Karena bentuk pemahaman peserta didik yang lebih mengandalkan guru sebagai sumber utama dalam belajar matematika menjadikan guru kurang dapat memberikan pembelajaran yang baik bagi peserta didiknya. Terlebih lagi jika penyajian matematika yang membutuhkan penguasaan konsep dan prosedur oleh peserta didik. Bahkan salah satu guru juga mengakui bahwa terkadang materi yang diberikan dirasa belum benar-benar dipahami oleh peserta didik, meskipun begitu guru tersebut tetap harus melanjutkan pembelajarannya pada materi selanjutnya karena berburu dengan terselesaikannya materi pada buku paket matematika.

Sementara dua guru lainnya, justru lebih mengutamakan pemahaman peserta didiknya. Menurut mereka, jika dapat menyelesaikan materi dalam satu buku paket secara utuh, namun kemampuan siswa tidak mencapai itu lantas untuk apa?. Justru nantinya akan menjadi sulit baginya pada jenjang selanjutnya, karena penguasaan dan pemahamannya masih belum baik.

Selanjutnya, terikat pemahaman guru pada konten geometri. Peneliti memberikan angket kepada ketiga guru tersebut untuk diisikan, yang mana angket tersebut terdiri dari 10 peryataan dan bentuk angket adalah angket terbuka yang didalamnya dapat diberikan jawaban tertulis dan alasan dari jawaban tersebut. Selain itu, juga terdapat empat soal tes pemahaman konten geometri. Berikut 10 pernyataan yang terdapat dalam angket pemahaman konten geometri. 
Tabel 3. Angket pemahaman guru terkait konten geometri

\begin{tabular}{|c|c|c|}
\hline No & Pernyataan & Jawaban \\
\hline 1 & $\begin{array}{l}\text { Saya membuat rencana pelaksanaan pembelajaran terkait konten geometri dengan } \\
\text { menyesuaikan pada kemampuan peserta didik. } \\
\text { Alasan: ... }\end{array}$ & Ya/Tidak \\
\hline 2 & $\begin{array}{l}\text { Saya memahami dengan baik konten geometri yang akan saya ajarkan } \\
\text { Alasan: ... }\end{array}$ & Ya/Tidak \\
\hline 3 & $\begin{array}{l}\text { Waktu untuk mengajarkan materi terkait konten geometri lebih banyak dari materi } \\
\text { lainnya } \\
\text { Alasan: ... }\end{array}$ & Ya/Tidak \\
\hline 4 & $\begin{array}{l}\text { Saya menggunakan media pembelajaran untuk menyajikan materi terkait konten } \\
\text { geometri } \\
\text { Alasan: ... }\end{array}$ & Ya/Tidak \\
\hline 5 & $\begin{array}{l}\text { Saya sering menggunakan metode/model/pendekatan pembelajaran lain yang disesuaikan } \\
\text { dengan materi terkait konten geometri } \\
\text { Alasan: ... }\end{array}$ & Ya/Tidak \\
\hline 6 & $\begin{array}{l}\text { Saya memahami dengan benar, materi terkait konten geometri dan dapat digunakan } \\
\text { dalam disiplin ilmu lainnya } \\
\text { Alasan: ... }\end{array}$ & Ya/Tidak \\
\hline 7 & $\begin{array}{l}\text { Saya meminta siswa untuk menghafal rumus dan menerapkannya ketika diberikan } \\
\text { permasalahan } \\
\text { Alasan: ... }\end{array}$ & Ya/Tidak \\
\hline 8 & $\begin{array}{l}\text { Belajar menggunakan pendekatan praktik sangat penting dan membantu dalam } \\
\text { memahami konten geometri } \\
\text { Alasan: ... } \\
\text { Saya sering membangun konsep materi dan bagaimana konsep itu berhubungan dengan }\end{array}$ & Ya/Tidak \\
\hline 9 & $\begin{array}{l}\text { konsep materi matematika lainnya } \\
\text { Alasan: ... }\end{array}$ & Ya/Tidak \\
\hline 10 & $\begin{array}{l}\text { Saya tidak menemui masalah ketika mengajarkan materi terkait konten geometri } \\
\text { Alasan: ... }\end{array}$ & Ya/Tidak \\
\hline
\end{tabular}

Setelah ketiga responden selesai mengisi angket yang diberikan, kemudian peneliti melakukan wawancara berdasarkan hasil yang diperoleh dari pengisian angket yang ada. Berikut penjelasan bentuk analisis masing-masing responden.

\section{Responden 1}

Pada pengisian angket diatas, responden memilih "Tidak" sebanyak tiga pernyataan yaitu pernyataan nomor 4,5, dan 10. Sedangkan sisanya adalah "Ya". Pada alasannya, disebutkan bahwa pernyataan nomor 4 tidak digunakan media dikarenakan persiapan untuk membuat media terkait konten geometri itu sulit bagi guru tersebut. Namun hal ini bertolak belakang dengan pernyataan nomor 8 bahwa responden setuju jika untuk mengajarkan konten geometri sangat penting jika menggunakan pendekatan praktik. Yang mana responden menyatakan bahwa praktik yang ia maksudkan adalah praktik menyelesaikan masalah matematika (soal).

Kemudian pada pernyataan nomor 5, responden menjawab "Tidak" dengan alasan bahwa ia lebih memilih untuk menyajikan materi dengan metode ceramah dan pengerjaan soal, dikarenakan untuk menyesuaikan dengan model/metode lain itu akan banyak menyita waktu belajar di kelas. Selanjutnya pada pernyataan nomor 10 , responden juga memilih "Tidak" dikarenakan responden mengakui bahwa ia sering mengalami masalah ketika mengajarkan materi kepada peserta didik, dan itu bukan hanya untuk materi terkait konten geometri saja. Salah satu masalah yang terjadi adalah kondisi kelas yang tidak kondusif, sehingga mengganggu aktivitas belajar. Selain itu, tidak siapnya peserta didik dalam menerima materi, menjadikan responden sering mengulang apa yang 
disampaikan didepan kelas. Sehingga menghambat terselesaikannya materi pada pertemuan yang ditentukan.

\section{Responden 2}

Pada pengisian angket, responden memilih "Ya" pada delapan pernyataan, yaitu pernyataan nomor 1 sampai 8 . Sedangkan untuk pernyataan nomor 9 dan 10, responden memilih "Tidak". Menurut responden, pernyataan nomor 9 yaitu "saya sering membangun konsep materi dan bagaimana konsep itu berhubungan dengan konsep materi matematika lainnya" sering ia lewati. Hal ini karena, responden lebih memilih untuk membangun konsep pada satu materi saja sesuai dengan materi yang diajarkan pada pertemuan dikelas.

Menurut responden, ia lebih memilih demikian karena untuk membangun satu konsep dan benar-benar dipahami oleh peserta didik butuh waktu dalam pertemuan tersebut. Selain itu, ia juga mengakui bahwa untuk mengantisipasi kesalahan dalam memahami konsep yang disampaikan maka ia menggunakan media pembelajaran. Sehingga peserta didik lebih memahami dan tahu betul maksud dari konsep yang dibangun. Ia juga mengatakan bahwa jika matematika, apalagi konten geometri (bangun datar) justru lebih baik jika menggunakan media sehingga peserta didik dapat langsung memperagakannya. Karena apa yang diperagakan olehnya akan lebih dipahami dan lebih lama diingat oleh peserta didik nantinya. Selain itu, responden juga sering menggunakan pendekatan realistik matematika dalam pembelajarannya.

Sedangkan pada pernyataan nomor 10, yaitu "saya tidak menemui masalah ketika mengajarkan materi terkait konten geometri", responden memilih "Tidak" karena ia sering mengalami kendala/masalah dalam pembelajaran. Dikarenakan terdapat peserta didik yang cukup sulit memahami materi yang disampaikan, meskipun telah menggunakan pendekatan realistik dalam pembelajaran. Sehingga responden harus mengulangi kembali apa yng telah disampakan. Namun, ia juga mengatakan bahwa ia tidak memburu target untuk harus menyelesaikan materi sesuai perencanaan semester.

Menurut respnden, jika harus mengejar target itu, maka akan menyusahkan peserta didik nantinya, "matematika kan spiral materinya, trus berhubungan dengan materimateri sebelumnya, kalau dilanjutin terus cuma mau kejar materi selesai, kan jadinya siswanya malah belum bisa tapi dipaksakan saja biar lewat materinya".

\section{Responden 3}

Pada pengisian angket oleh responden, ia memilih "Ya" pada enam pernyataan. Sedangkan pilihan "Tidak" pada empat pernyataan yaitu pada pernyataan nomor $1,5,9$, dan 10 . Yang mana pada pernyataan nomor 1 yaitu "saya membuat rencana pelaksanaan pembelajaran terkait konten geometri dengan menyesuaikan pada kemampuan peserta didik", responden memilih "Tidak" dengan alasan bahwa rencana yang tertulis pada RPP itu tidak melihat pada kemampuan peserta didik. Namun jika pelakasnaannya harus menyesuaikan dengan kemampuan peserta didik. Selanjutnya pada pernyataan 5 yaitu "saya sering menggunakan metode/model/ pendekatan pembelajaran lain yang disesuaikan dengan materi terkait konten geometri", responden juga memilih "Tidak" dengan alasan bahwa untuk menyajikan pembelajaran dengan berbagai metode/ model/pendekatan itu akan menjadi sulit diimplementasikan, karena perlu pengenalan tentang metode/model itu untuk peserta didik terlebih dulu. Sehingga waktu pembelajaran justru terpakai, jadi lebih baik saya mengajarkan materi dengan metode yang telah biasa saya digunakan.

Kemudian pada pernyataan nomor 9 yaitu "saya sering membangun konsep materi dan bagaimana konsep itu berhubungan dengan konsep materi matematika lainnya", responden juga 


\section{$\pi$ (Phi)}

memilih "Tidak", karena menurut responden untuk membangun konsep materi kepada peserta didik itu sedikit sulit, apalagi meminta peserta didik untuk mencoba mengubungkan dengan konsep lainnya. Sehingga terkadang waktu belajar juga terpakai banyak untuk membangun konsep kepada peserta didik. Ini juga menjadi alasan bahwa responden memilih "Tidak " pada pernyataan 10 .

Selain itu responden juga mengatakan bahwa meskipun peserta didik diajak untuk

Tabel 4. Soal pemahaman guru terkait konten geometri

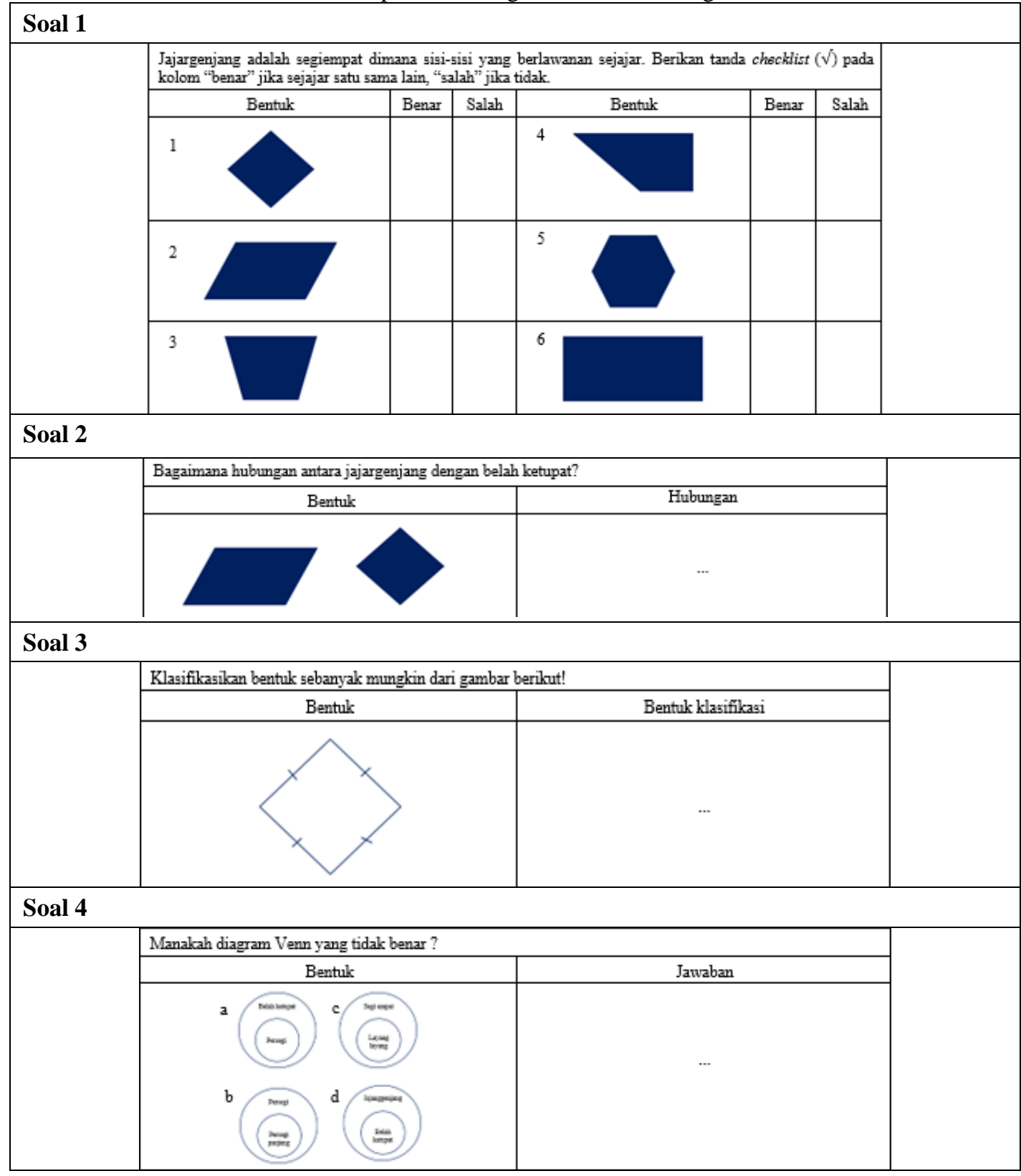


Tes yang diberikan bertujuan untuk mengetahui pemahaman guru tekait konten geometri sebelum mengajarkannya kepada peserta didik. Tes ini digunakan hanya untuk mengetahui sejauh mana pemahaman responden tentang konten geometri. Adapun hasil yang diperoleh dijadikan dalam bentuk tabel, seperti berikut:

Tabel 5. Rekapan tes pemahaman guru terkait konten geometri

\begin{tabular}{|c|c|c|c|}
\hline \multirow{2}{*}{$\begin{array}{l}\text { Nomor } \\
\text { Soal }\end{array}$} & \multicolumn{3}{|c|}{ Jawaban } \\
\hline & Responden 1 & Responden 2 & Responden 3 \\
\hline 1 & $1,2,3$, dan 6 & 1,2, dan 6 & 1,2, dan 6 \\
\hline 2 & $\begin{array}{l}\text { Belah ketupat itu } \\
\text { jajargenjang }\end{array}$ & $\begin{array}{l}\text { Belah ketupat itu jajargenjang } \\
\text { yang mempunyai sepasang sisi } \\
\text { yang berdekatan dan kongruen }\end{array}$ & $\begin{array}{l}\text { Belah ketupat itu } \\
\text { jajargenjang karena memiliki } \\
\text { sisi yang kongruen }\end{array}$ \\
\hline 3 & $\begin{array}{l}\text { Persegi, segi empat, } \\
\text { belah ketupat }\end{array}$ & $\begin{array}{l}\text { Persegi, persegi panjang, } \\
\text { segiempat, belah ketupat }\end{array}$ & $\begin{array}{c}\text { Segiempat, } \\
\text { persegi, belah ketupat }\end{array}$ \\
\hline 4 & $\begin{array}{l}\text { a. Persegi bagian dari } \\
\text { belah ketupat }\end{array}$ & $\begin{array}{l}\text { b. Persegi panjang itu } \\
\text { bagian dari persegi }\end{array}$ & $\begin{array}{l}\text { b. Persegi panjang itu } \\
\text { bagian dari persegi }\end{array}$ \\
\hline
\end{tabular}

Jika dilihat berdasarkan pengisian tes pemahaman diatas, maka dapat dikatakan bahwa responden 2 lebih memahami dengan baik terkait konten geometri dari pada dua responden lainnya. Yang mana pada soal 1, bentuk ke-3 tidak dapat dikatakan sejajar, karena jika ditarik garisnya, maka akan ada perpotongan garis. Oleh karena itu, yang termasuk hanya bentuk 1,2, dan 6 .

Selanjutnya pada soal nomor 2, responden 1 tidak dengan detail menjelaskan hubungan antara jajargejang dan belah ketupat. Jika mengikuti pada jawaban responden 1 bahwa "belah ketupat itu jajargenjang" akan menghasilkan kesalahan penyelesaian masalah matematika nantinya. Akan lebih baik jika penjelasannya detail seperti yang dilakukan oleh responden 2 bahwa " belah ketupat itu jajargenjang yang mempunyai sepasang sisi yang berdekatan dan kongruen", sehingga peserta didik nantinya juga akan lebih paham bahwa, ada bagian dikatakan sama dengan alasan yang logis. Sedangkan responden 3 sudah dapat dengan baik menjelaskan hubungan antara jajargenjang dengan belah ketupat, namun tidak menyertakan bagian/sisi mana yang kongruen atau sebagainya.

Sedangkan pada soal 3, ketiga responden dapat dengan mudah menentukan klasifikasi bentuk dari sebuah gambar yang diberikan pada soal. Namun jika dilihat dengan baik, maka seharusnya terdapat lima klasifikasi bentuk yaitu persegi, persegi panjang, seiempat, belah ketupat, dan jajargenjang. Namun ketiga responden tidak dengan lengkap membuat klasifikasi tersebut. sehingga dapat dikatakan bahwa responden kurang jeli dalam melihat bentuk geometri dan membuat klasifikasi sesuai bentuk yang ada.

Kemudian pada soal nomor 4, yang benar menjawab adalah responden 2 dan responden 3 bahwa pernyataan yang salah pada soal berbentuk diagram venn yaitu "persegi panjang itu bagian dari persegi'. Berbeda dengan responden 1 yang menjawab bahwa "persegi bagian dari belah ketupat".

\section{SIMPULAN DAN SARAN}

Berdasarkan analisis yang dilakukan sebelumnya, maka dapat disimpulkan bahwa meskipun responden telah menyiapkan rencana pelaksanaan pembelajaran dengan baik dan mengikuti kebijakan kurikulum yang ada, namun pada pelaksanaannya menjadi kurang maksimal dan bahkan responden kurang dapat memahami apa yang akan disampaikan kepada peserta didiknya. 


\section{$\pi$ (Phi)}

Meskipun terdapat responden yang telah baik dalam perencanaan pembelajaran dan pemahamannya terkait konten geometri, namun masih memerlukan usaha lanjut olehnya untuk menjadikan pembelajarannya lebih baik.

Adapun saran yang dapat disampaikan adalah perlunya peningkatan dalam pemahaman dan perencanaan pembelajaran terkait konten geometri oleh guru matematika.

\section{UCAPAN TERIMA KASIH}

Penelitian ini terselenggara dari Dana Hibah Penelitian Dosen Pemula Anggaran tahun 2020 oleh Deputi Bidang Penguatan Riset dan Pengembangan Kementerian Riset dan Teknologi/ Badan Riset dan Inovasi Nasional, berdasarkan SK Nomor: 8/E1/KPT/SP3/Peneliti/III/2020.

Sehubungan dengan hal tersebut, kami menyampaikan terima kasih dan perhargaan setinggi-tingginya.

\section{DAFTAR PUSTAKA}

Ball, D. (2000). Bridging Practices: Intertwining Content and Pedagogy in Teaching and Learning to Teach. Journal of Teacher Education, 51, 241247.

Ball, D.L., Thames, M.H., \& Phelps, G. (2008). Content Knowledge for Teaching: What Makes It Special? Journal of Teacher Education, 59(5), 389-407.

https://doi.org/10.1177/0022487108324 554

Chiwiye, T. (2012). Assesment of Mathematics and Science Subject in Zimbabwe. In L. . Kusure \& K. Basira (Eds.), Instruction in Science and Mathematics for the 21st Century (pp. 5-7). Faculty of Science Education, Bindura University of Science Education.

Ekowati, D.A. (2017). Ethnomathematica: Pembelajaran Matematika dalam Perspektif Budaya. Peningkatan
Jurnal Pendidikan Matematika

Volume 4 Nomor 2 Tahun 2020

\section{Kualitas Pembelajaran Matematika, 163-171.}

Gal, H. (2011). From Another Perspective Training Teachers to Cope with Problematic Learning Situations in Geometry. Educational Studies in Mathematics, $\quad 78(2), \quad 183$. https://doi.org/10.1007/s10649-0119321-6

Hiele, P.M. (1959). Development and Learning Process: A Study of Some Aspects of Piaget's Psychology in Relation with the Didactics of Mathematics (17th ed.). Wolters. https://books.google.co.id/books?id=T3 OaHAAACAAJ

Kılıç, H. (2011). Preservice Secondary Mathematics Teachers Knowledge of Students. Turkish Online Journal of Qualitative Inquiry, 2(2), 17-35.

Kuzniak, A \& Rauscher, J.C. (2011). How do Teachers Approaches to Geometric Work Relate to Geometry Students Learning Difficulties? Educational Studies in Mathematics, 77(1), 129147. https://doi.org/10.1007/s10649011-9304-7

Mashingaidze, S. (2012). The teaching of geometric (isometric) transformations at secondary school level: What approach to use and why? Asian Social Science, 8(15), 197-210. https://doi.org/10.5539/ass.v8n15p197

Muijs, D \& Reynolds, D. (2002). Teachers Beliefs And Behaviours: What Really Matters? Journal of Calssroom Interaction, 37, 3-15.

Nasution, F.Y. (2018). Misconceptions Analysis of Students Junior High School In Solving Algebra Problems Term of Field Independent and Field Dependent Cognitive Styles. The International Conference on Mathematical Analysis, Its Application and Learning, 1-6. https://usd.ac.id/conference/icomaal/wp -content/uploads/2019/03/783-001.pdf

Pournara, C., Hodgen, J., \& Pillay, V. 
(2015). Can Improving Teachers Knowledge of Mathematics Lead to Gains in Learners Attainment in Mathematics? South African Journal of Education, 35(3), 1-10. https://doi.org/10.15700/saje.v35n3a10 83

Said, A \& Budimanjaya, A. (2015). 95 Strategi Mengajar. Prenadamedia Group.

Sandt, S.V. \& Nieuwoudt, H . (2003). Grade 7 Teachers and Prospective Teachers Content Knowledge of Geometry. South African Journal of Education, 23(3), 199-205.

Sunzuma, G \& Maharaj, A. (2019). Inservice Teachers Geometry Content Knowledge: Implications for How Geometry is Taught in Teacher
Training Institutions. International Electronic Journal of Mathematics Education, 15(1), 633-646. https://doi.org/10.29333/iejme/5776

Tutak, F. \& Adams, T. (2015). A Study of Geometry Content Knowledge of Elementary Preservice Teachers. International Electronic Jurnal of Elementary Education, 7(3), 301-318. www.iejee.com

Yilmaz, S., Kesan, C., Turgut, M., \& Kabakci, D. (2005). The Effect of Concept Map-Supported Problem Solving Centered Geometry Teaching on the Van Hiele Geometric Thinking Levels of the 7th Grade Students. 14th National Educational Sciences Congress. 